\title{
Inhibition Effect of Copper Complex of 1-(8-Hydroxy Quinolin-2-yl- Methyl) Thiourea on the Corrosion of Mild Steel in Sodium Chloride Solution
}

\author{
S.S. Syed Abuthahir ${ }^{*}, 1,2$, A. Jamal Abdul Nasser ${ }^{1}$ and S. Rajendran ${ }^{2}$ \\ ${ }^{I} P G \&$ Research Department of Chemistry, Jamal Mohamed College, Tiruchirappalli 620 020, India \\ ${ }^{2}$ Department of Chemistry, RVS School of Engineering and Technology, Dindigul-624 005, India
}

\begin{abstract}
The Corrosion inhibition of an inhibitor namely Copper complex of 1-(8-hydroxy quinolin-2-yl-methyl) thiourea $(\mathrm{Cu}-\mathrm{HTF})$ which controls the corrosion of mild steel immersed in an aqueous solution containing $60 \mathrm{ppm}^{-} \mathrm{Cl}^{-}$has been investigated through electrochemical and mass loss method. The formulation consisting of $60 \mathrm{ppm}$ of $\mathrm{Cl}^{-}$and $50 \mathrm{ppm}$ of $\mathrm{Cu}-\mathrm{HTF}$ offers good inhibition efficiency of $78 \%$. Polarization study shows that this formulation acts as a cathodic inhibitor.AC impedance spectra indicate that a protective film is formed on the mild steel surface. Fluorescence spectral analysis was used to detect the presence of iron-inhibitor complex. The surface morphology has been analyzed by FTIR, UV-Visible spectroscopy, Scanning Electron Microscope (SEM) and EDAX. Cu-HTF has the ability to prevent the growth of certain microorganisms such as E. coli, Streptococcus, Pseudomonas and Enterobacter.
\end{abstract}

Keywords: Biocidal activity, corrosion inhibition, EDAX, EIS, mild steel, SEM, transition metal complex.

\section{INTRODUCTION}

Mild steel is highly applicable and most widely used alloy of iron, comes in contact with chloride ions very frequently under numerous conditions and circumstances in industries. Chloride ions are known to be aggressive towards mild steel and cause severe corrosion problems. Various inorganic compounds have been reported as inhibitors for controlling corrosion of mild steel in water containing chloride ions [1]. The use of inhibitor is one of the most practical methods to protect metals from corrosion [2, 3]. Metal complexes are widely used as catalysts of chemical reactions, e.g. Oxidative dehydrogenation (ODH) of ethane and epoxidation of geraniol [4-6] and as stabilizers or precursors in sol-gel processes [7-9]. Very few works have been performed to study anticorrosive behavior of metal complexes. Harms et al. [10] proposed corrosion inhibition through precipitation of $\mathrm{Fe}(\mathrm{II})$ phosphate and $\mathrm{Fe}(\mathrm{III})$ phosphate in presence of $\mathrm{Fe}$ (III) acetylacetonate and $\mathrm{Fe}$ (II) acetylacetonate respectively. Palladium acetylacetonate is suggested as an effective corrosion inhibitor for water cooled nuclear reactor [11]. Interaction of transition metal complexes with mild steel is greatly affected by their standard electrode potentials, their reactivity and the nature of the ligand that could stabilize the metallic complexes. Reduction of $\mathrm{Cu}$ (II) and $\mathrm{Co}$ (II) species on mild steel surface is possible due to their noble standard electrode potential compared to Fe (II). However, it should be noted that negative charged ligands like nitro, thiocyanate, Oxalato, glucinato and acetylacetonate could stabilize the

*Address correspondence to these authors at the PG \& Research Department of Chemistry, Jamal Mohamed College, Tiruchirappalli 620 020, India; Tel: +91 9965875638; E-mail : syedchem05@gmail.com higher oxidation states [12]. The aim of the present work is to evaluate corrosion inhibitive performance of copper complex of 1-(8-hydroxy quinolin-2-yl-methyl) thiourea to mild steel immersed in the aqueous solution containing 60 ppm $\mathrm{Cl}^{-}$. The corrosion inhibition efficiency was evaluated using mass loss method and electrochemical impedance spectroscopy. The protective film formed on the mild steel surface was characterized with the help of surface analytical techniques such as fluorescence, FTIR and UV-Visible spectroscopy. The surface morphology has been analyzed by SEM and EDAX. The importance of this work is to study the surface analysis from energy dispersive analysis that is used to identify the elements present on mild steel surface. From that we understand that the surface film is formed over the mild steel surface. From SEM analysis we predict the smoothness of mild steel surface with and without inhibitor system. The Biocidal efficiencies of the system are also measured against certain organisms such as E. coli, Streptococcus, Pseudomonas and Enterobacter. From that biocidal efficiency study we measured the bacterial growth with and without inhibitor system. In the presence of inhibitor system, less bacterial growth is observed which implies that the rate of corrosion will be minimized due to a lower bacterial count in corrosive media.

\section{MATERIALS AND METHODS}

Mild steel specimens; $(0.026 \% \mathrm{~S}, 0.068 \% \mathrm{P}, 0.36 \% \mathrm{Mn}$, $0.13 \% \mathrm{C}$ and the rest iron) of dimensions $1.0 \mathrm{~cm} \times 4.0 \times 0.2 \mathrm{~cm}$ were polished to mirrors finish and degreased with acetone and used for mass loss method.

\section{Mass Loss Method}

Mild steel specimen triplicate were immersed in $100 \mathrm{ml}$ beaker containing $100 \mathrm{ml}$ of an aqueous solution containing 
$60 \mathrm{ppm}$ of $\mathrm{Cl}^{-}$containing various concentrations of the $\mathrm{Cu}$ complex of 1-(8-hydroxy quinolin-2-yl-methyl) thiourea inhibitor which is prepared by the standard available method $[13,14]$ for one day. After $24 \mathrm{hrs}$ immersions the specimens were taken out, washed in running water, dried and weighed using a Shimadzu balance, model AY62.

The corrosion inhibition efficiency (IE) was calculated using the equation:

$\mathrm{IE}=100\left[1-\left(\mathrm{w}_{2}-\mathrm{w}_{1}\right)\right] \%$

where $\mathrm{w}_{1}$ is the weight loss in the absence of inhibitor and $\mathrm{w}_{2}$ is weight loss in the presence of inhibitor.

\section{Potentiodynamic Polarization Study}

Polarization studies were carried out in an $\mathrm{H} \& \mathrm{CH}$ electrochemical work station impedance analyzer model CHI 643B, Austin, USA using three electrode cell assemblies. The working electrode was mild steel with one face of the electrode of constant $1 \mathrm{~cm}^{2}$ area exposed and the rest being shield with red lacquer. A saturated calomel electrode (SCE) was used as the reference electrode and a rectangular platinum foil was used as the counter electrode. The area of the counter electrode was much larger when compared to the area of the working electrode. This can exert a uniform potential field on the counter electrode. The results such as the Tafel slopes, Corrosion Current ( $\left.\mathrm{I}_{\text {corr }}\right)$, Corrosion Potential $\left(\mathrm{E}_{\text {corr }}\right)$ and Linear Polarisation Resistance (LPR) values were calculated.

The working electrode and platinum electrode were immersed in an aqueous solution containing $60 \mathrm{ppm}^{-}$in the absence and presence of inhibitor. Saturated calomel electrode was connected with the test solution through a salt bridge. Potential (E) Vs log current (I) plots were recorded. Corrosion potential $\left(E_{\text {corr }}\right)$ and Tafel slopes $b_{a}, b_{c}$ were determined from $\mathrm{E}$ Vs $\log$ I plots.

\section{AC Impedance Spectra}

The instrument used for polarization study was also employed for AC impedance spectra. The cell set up was the same as that was used for potentiodynamic polarization measurements. The real part (Z') and the imaginary part (Z') of the cell impedance were measured in ohms $(\Omega)$ at various frequencies. AC impedance spectra were recorded with initials $\mathrm{E}_{(\mathrm{v})}=0 \mathrm{~V}$, high frequency limit was $1 \times 10^{5} \mathrm{~Hz}$, low frequency limit was $1 \mathrm{~Hz}$, amplitude $=0.005 \mathrm{~V}$ and quiet time $t_{q}=2 \mathrm{~s}$. The values of charge transfer resistance $R_{t}$ and the double layer capacitance $\mathrm{C}_{\mathrm{dl}}$ were calculated.

$\mathrm{C}_{\mathrm{dl}}=1 / 2 \pi \mathrm{R}_{\mathrm{t}} \mathrm{f}_{\max }$

where $f_{\max }$ is maximum frequency.

\section{Surface Characterization Studies}

The mid steel specimens were immersed in various test solutions for a period of $24 \mathrm{hrs}$. Then mild steel specimens were taken out and dried. The nature of the film formed on the surface of the mild steel specimen was analyzed by various surface analysis techniques.

\section{Surface Analysis by UV-Visible Spectroscopy}

UV-Visible spectra were recorded in a Cary Eclipse Varian (Model U.3400) spectrophotometer.

\section{Surface Analysis by Fluorescence Spectroscopy}

Fluorescence spectra of solutions and also the films formed on the mild steel surface were recorded using JascoF-6300 spectra fluorometer.

\section{Surface Analysis by FTIR Spectroscopy}

The spectra were recorded in a bruker (Model Tensor 27) spectrophotometer. The film was scratched with sharp glass spatula, mixed thoroughly with $\mathrm{KBr}$ and made into pellets and the FTIR spectra were recorded.

\section{SEM Analysis}

SEM (Tescan, Vega 3, USA) provides a pictorial representation in the surface to understand the nature of the surface film in the absence and presence of inhibitors and extent of corrosion of mild steel. The SEM micrographs of the surface are examined.

\section{Energy Dispersive Analysis of X-Rays (EDAXs)}

The mild steel specimen immersed in blank and in the inhibitor solution for a period of $24 \mathrm{hrs}$ was removed, dried and observed in an Energy Dispersive Analysis of X-rays (EDAXs) to examine the elements present on the mild steel surface. The elements present on the mild steel surface were examined using bruker computer controlled Energy Dispersive Analysis of X-rays (Brucker, Nano, GMBH, Germany).

\section{Bacterial Enumeration}

Bacterial cell are count based on their colony forming unit (CFU) by standard plate count. The protocols are as follows. Label the plate $10^{-2}, 10^{-4}, 10^{-6}$ and $10^{-8}$ at the bottom of plate and one plate as a blank or control. Transfer $1 \mathrm{ml}$ of four different cultures to $99 \mathrm{ml}$ of sterile saline blank using aseptic technique. A test tube labelled $10^{-2}$ and the dilution is proceeded by taking $1 \mathrm{ml}$ from $10^{-2}$ test tube to the next $99 \mathrm{ml}$ sterile saline blank labeled as to the next $99 \mathrm{ml}$ sterile saline blank labeled as $10^{-4}$ and proceed until $10^{-8}$. Shake all the test tubes for equal distribution of bacteria. Transfer $1 \mathrm{ml}$ of the sample into each of the labelled plates $10^{-2}$ to $10^{-8}$ correspondingly. All the plates containing agar medium are immersed and incubated at $37^{\circ} \mathrm{C}$ for 24 hours. After the incubation, select the plate containing 30 to 300 colonies and count the colonies. The number of CFU are calculated as

CFUs/dilution $\times$ amount plated $=$ No. of bacterial cell $/ \mathrm{ml}$.

\section{RESULTS AND DISCUSSION}

The corrosion rates (CR) of mild steel immersed in an aqueous solution containing $60 \mathrm{ppm} \mathrm{Cl}^{-}$and also inhibition efficiencies(IE) in the absence and presence of inhibitor of copper complex of 1-(8-hydroxy quinolin-2-yl-methyl) thiourea obtained by mass loss method are given in Table $\mathbf{1}$. It is observed from Table 1 that $\mathrm{Cu}-\mathrm{HTF}$ shows $79 \%$ inhibition efficiency. As the concentration of inhibitor increases, the inhibition efficiency decreases. This may be due to the fact that as the concentration of inhibitor increases, the protective film is formed on the mild steel surface goes into solution. Similar observation has been made by Sahaya Raja et al. while studying the controlling corrosion of mild steel in well water by Eco-friendly inhibitor glycine- $\mathrm{Zn}^{2+}$ system [15]. 
Table 1. Corrosion rates (CR) of mild steel immersed in an aqueous solution containing $60 \mathrm{ppm} \mathrm{Cl}^{-}$in the absence and presence of $\mathrm{Cu}-\mathrm{HTF}$ inhibitor systems at various concentrations and the inhibition efficiency (IE \%) obtained by mass loss method.

\begin{tabular}{|c|c|c|c|}
\hline $\mathbf{C l}^{-}$(ppm) & Cu-HTF (ppm) & CR (mdd) & IE (\%) \\
\hline \hline 60 & 0 & 34.55 & - \\
\hline 60 & 50 & 13.82 & 79 \\
\hline 60 & 100 & 15.54 & 70 \\
\hline 60 & 150 & 16.23 & 61 \\
\hline 60 & 200 & 18.31 & 55 \\
\hline 60 & 250 & 20.03 & 49 \\
\hline
\end{tabular}

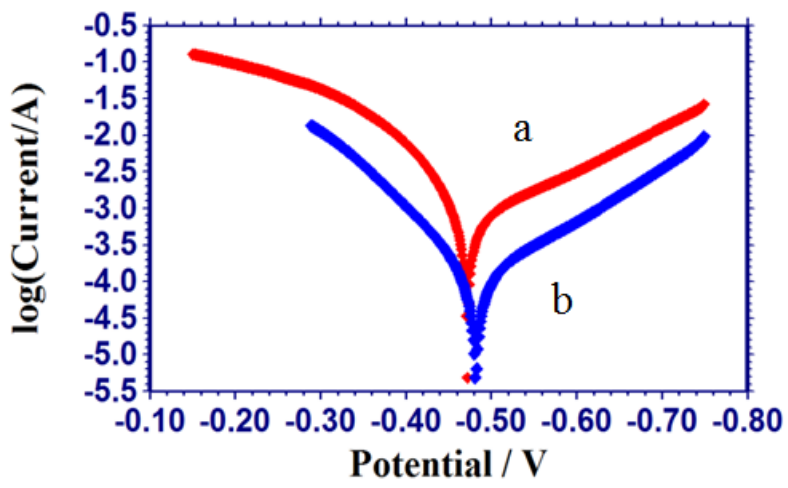

Fig. (1). Polarization curve of mild steel immersed in the various test solutions: a) Mild steel is immersed in an aqueous solution containing $60 \mathrm{ppm}$ of $\mathrm{Cl}^{-}$. b) Mild steel is immersed in an aqueous solution containing $60 \mathrm{ppm}$ of $\mathrm{Cl}^{--}+50 \mathrm{ppm}$ of $\mathrm{Cu}-\mathrm{HTF}$.

\section{Analysis of Polarization Curves}

The polarization study has been worn to investigate the formation of protective film on mild steel surface [16-19]. The polarization curves of mild steel immersed in an aqueous solution containing $60 \mathrm{ppm}$ of $\mathrm{Cl}^{-}$are shown in Fig. (1). The corrosion parameters such as corrosion potential $\left(\mathrm{E}_{\mathrm{corr}}\right)$, corrosion current density $\left(I_{\text {corr }}\right.$, Tafel slopes $\left(b_{c}\right.$ and $\left.b_{a}\right)$ and linear polarization resistance (LPR) are given in Table 2 .
When mild steel is immersed in the aqueous solution containing $60 \mathrm{ppm}$ of $\mathrm{Cl}^{-}$, the corrosion potential is $-472 \mathrm{mV}$ Vs SCE. The formulation consisting of $50 \mathrm{ppm}$ of $\mathrm{Cu}-\mathrm{HTF}$ shifts the corrosion potential to $-482 \mathrm{mV}$ Vs SCE (cathodic shift). It shows that the corrosion potential is shifted to negative side. This suggests that the cathodic reaction is controlled predominantly.

The corrosion current density value and LPR value for an aqueous solution containing $60 \mathrm{ppm}$ of $\mathrm{Cl}^{-}$are $1.261 \times 10^{-3} \mathrm{~A} \mathrm{~cm}^{-2}$ and $25.74 \Omega \mathrm{cm}^{2}$ respectively. For the formulation of $50 \mathrm{ppm}$ of $\mathrm{Cu}-\mathrm{HTF}$ the corrosion density value has decreased from $1.261 \times 10^{-3} \mathrm{~A} \mathrm{~cm}^{-2}$ to $1.378 \times 10^{-4} \mathrm{~A} \mathrm{~cm}^{-2}$ and the LPR value has increased from $25.74 \Omega \mathrm{cm}^{2}$ to $177.5 \Omega \mathrm{cm}^{2}$. The fact that the LPR value increases with decrease in corrosion current density indicates the absorption of the inhibitor on the mild steel surface to block the active sites, inhibit corrosion and reduce the corrosion rate with the formation of a protective film on the mild steel surface.

\section{AC Impedance Spectra}

AC impedance spectra [electrochemical impedance spectra] have been used to confirm the formation of protective film on the mild steel surface [20-22]. The AC impedance spectra of mild steel immersed in an aqueous solution containing $60 \mathrm{ppm}$ of $\mathrm{Cl}^{-}$in the absence and presence of inhibitors are shown in (Fig. 2, Nyquist plots) and (Fig. 3, Bode plots). The impedance parameters namely charge transfer resistance $\left(R_{t}\right)$, double layer capacitance $\left(C_{d 1}\right)$ and impedance $\lg (\mathrm{z} / \Omega)$ are given in Table 3 . If a protective film is formed on the mild steel surface, $R_{t}$ value increases and the $\mathrm{C}_{\mathrm{dl}}$ value decreases.

When mild steel is immersed in an aqueous solution containing $60 \mathrm{ppm}$ of $\mathrm{Cl}^{-}, \mathrm{R}_{\mathrm{t}}$ value is $20.19 \Omega \mathrm{cm}^{2}$ and $\mathrm{C}_{\mathrm{dl}}$ value is $5.235 \times 10^{-5} \mathrm{~F} \mathrm{~cm}^{-2}$. When $\mathrm{Cu}-\mathrm{HTF}$ is added to the aqueous solution containing $60 \mathrm{ppm}$ of $\mathrm{Cl}^{-}, \mathrm{R}_{t}$ value increases from $20.19 \Omega \mathrm{cm}^{2}$ to $117.48 \Omega \mathrm{cm}^{2}$ and the $\mathrm{C}_{\mathrm{dl}}$ value decreases from $5.235 \times 10^{-5} \mathrm{~F} \mathrm{~cm}^{-2}$ to $8.997 \times 10^{-6} \mathrm{~F} \mathrm{~cm}^{-2}$. The impedance value increases from 0.973 to 1.48 . This accounts for the high inhibition efficiency of $\mathrm{Cu}-\mathrm{HTF}$ system and a protective film is formed on the mild steel surface. This is also supported by the fact that for the inhibitor system the phase angle increases from 47.88 to $56.54^{\circ}$ (Fig. 3).

Table 2. Corrosion parameters of mild steel in an aqueous solution containing $60 \mathrm{ppm}$ of $\mathrm{Cl}^{-}$in the absence and presence of $\mathrm{Cu}$ HTF inhibitor obtained by polarization method.

\begin{tabular}{|c|c|c|c|c|c|}
\hline Systems & $\mathbf{E}_{\text {corr }}(\mathbf{m V}$ vs $\mathbf{S C E})$ & $\mathbf{I}_{\mathbf{c o r r}}\left(\mathbf{A} / \mathbf{c m}^{2}\right)$ & $\mathbf{b}_{\mathbf{a}}(\mathbf{m V} / \mathbf{d e c})$ & $\mathbf{b}_{\mathbf{c}}(\mathbf{m V} / \mathbf{d e c})$ & $\left.\mathbf{L P R}(\boldsymbol{\Omega} \mathbf{c m})^{2}\right)$ \\
\hline \hline $60 \mathrm{ppmCl}^{-}$ & -472 & $1.261 \times 10^{-3}$ & 124 & 187 & 25.74 \\
\hline $60 \mathrm{ppm} \mathrm{Cl}+50 \mathrm{ppm} \mathrm{Cu}-\mathrm{HTF}$ & -482 & $1.378 \times 10^{-4}$ & 090 & 149 & 177.5 \\
\hline
\end{tabular}

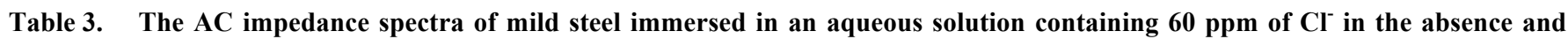
presence of $\mathrm{Cu}-\mathrm{HTF}$ inhibitor system.

\begin{tabular}{|c|c|c|c|}
\hline Systems & $\mathbf{R}_{\mathbf{t}} \mathbf{\Omega ~ c m}^{2}$ & $\mathbf{C}_{\mathrm{dl}} \mathbf{F} \mathbf{~ c m}^{-2}$ & Impedance, Log (Z $\left.\mathbf{\Omega}^{-1}\right)$ \\
\hline \hline $60 \mathrm{ppm} \mathrm{Cl}$ & 20.19 & $5.235 \times 10^{-5}$ & 0.973 \\
\hline $60 \mathrm{ppm} \mathrm{Cl}+50 \mathrm{ppm} \mathrm{Cu}-\mathrm{HTF}$ & 117.48 & $8.9972 \times 10^{-6}$ & 1.48 \\
\hline
\end{tabular}




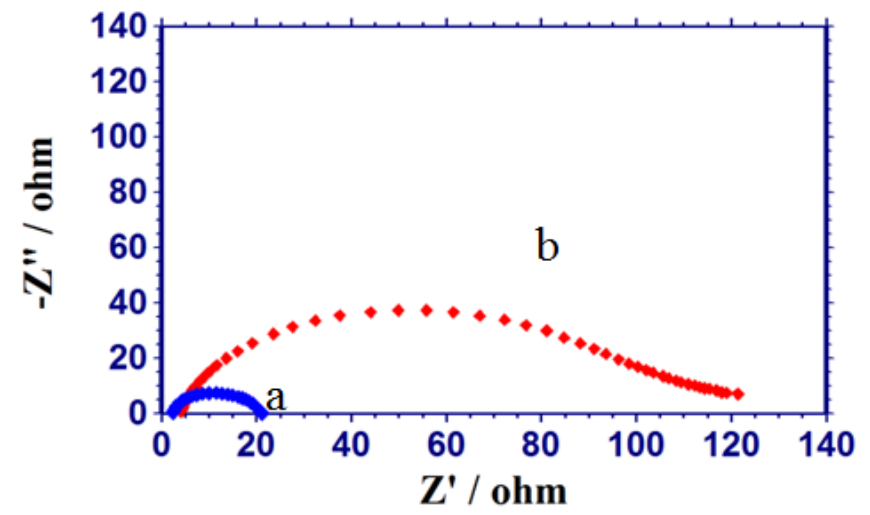

Fig. (2). AC impedance spectra (Nyquist plots) of mild steel is immersed in the various test solutions a) aqueous solution containing $60 \mathrm{ppm}$ of $\mathrm{Cl}^{-}$. b) aqueous solution containing $60 \mathrm{ppm}$ $\mathrm{Cl}^{-}+50 \mathrm{ppm} \mathrm{Cu}-\mathrm{HTF}$

\section{Analysis of the UV-Visible Spectra}

The UV-Visible absorption spectrum of an aqueous solution containing $\mathrm{Cu}-\mathrm{HTF}$ is shown in Fig. (4). Peaks appear at $300 \mathrm{~nm}$ and $380 \mathrm{~nm}$. When $\mathrm{Fe}^{2+}$ solution is added to the solution new peaks appear at $450 \mathrm{~nm}$ and $620 \mathrm{~nm}$. There is an increase in intensity of peaks also. This confirms the formation of $\mathrm{Fe}^{2+}$-HTF complex in solution [23].

\section{Fluorescence Spectra}

The emission spectrum $\left(\lambda_{\mathrm{ex}}: 400 \mathrm{~nm}\right)$ of solution containing HTF-Fe ${ }^{2+}$ solution is shown in Fig. (5a). Peaks appear at 380 $\mathrm{nm}$ and $420 \mathrm{~nm}$. This is due to HTF-Fe ${ }^{2+}$ complex which is formed in the solution. The emission spectrum of the film formed on the mild steel surface after immersion in solution containing $50 \mathrm{ppm}$ of $\mathrm{Cu}-\mathrm{HTF}$ is shown in Fig. (5b). Peaks appear at $380 \mathrm{~nm}$ and $440 \mathrm{~nm}$. Hence it is concluded that the formed protective film consists of $\mathrm{HTF}-\mathrm{Fe}^{2+}$ complex. The number of peaks obtained is only one. Hence it is confirmed that the complex is highly symmetric in solution [24].
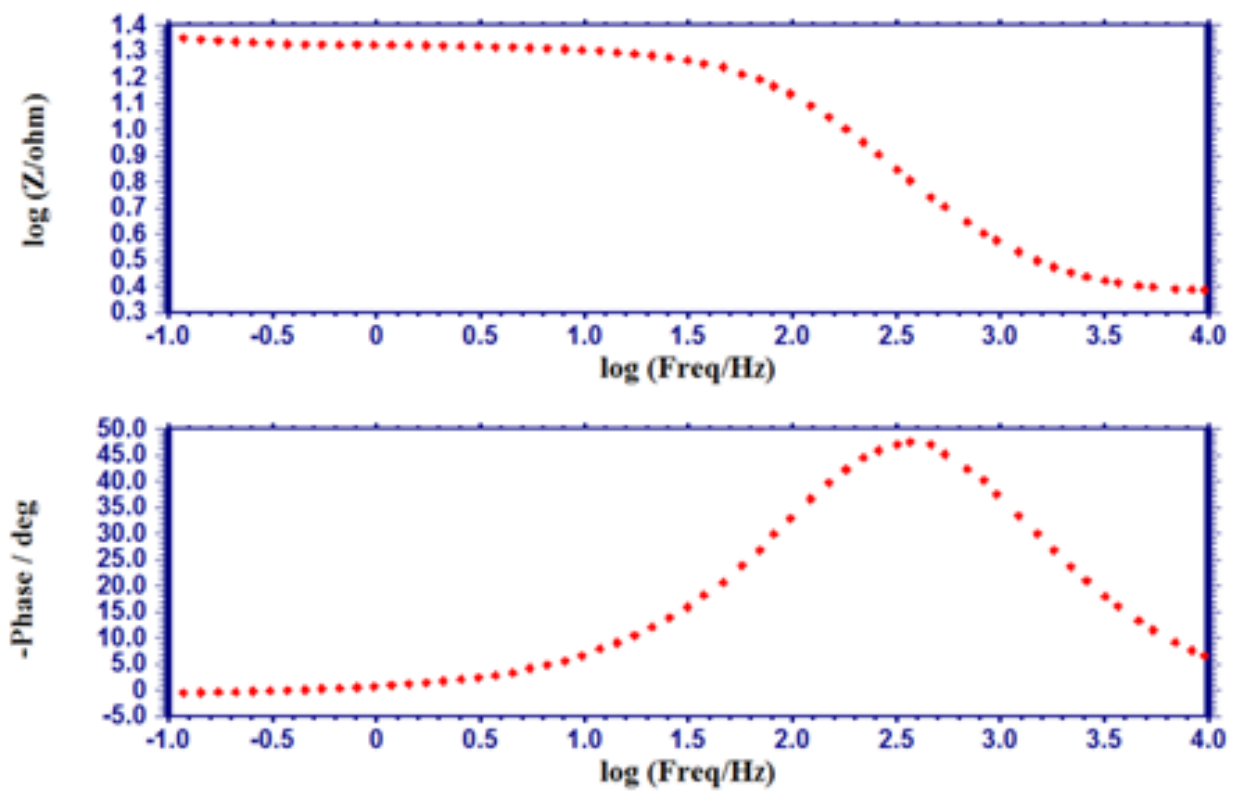

Fig. (3a). AC impedance spectra (Bode Plot) of mild steel immersed in an aqueous solution containing $60 \mathrm{ppm}$ of $\mathrm{Cl}^{-}$.
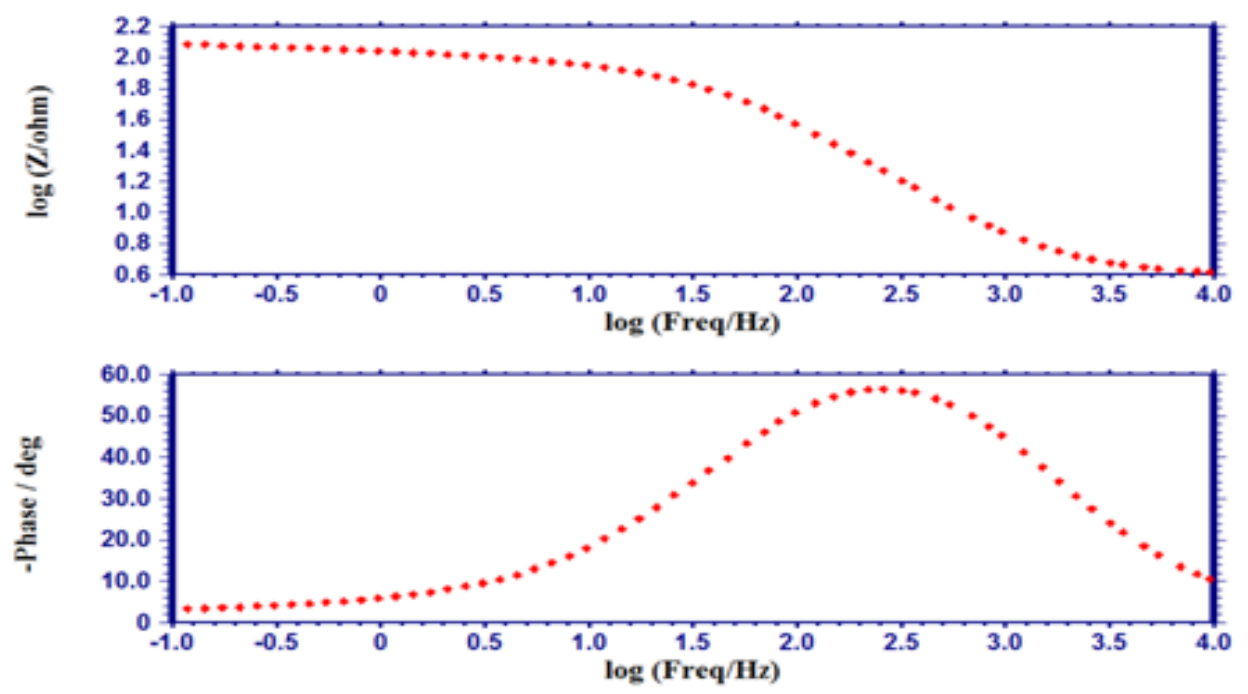

Fig. (3b). AC impedance spectra (Bode Plot) of mild steel immersed in the solution containing $60 \mathrm{ppm}$ of $\mathrm{Cl}^{-}+50 \mathrm{ppm}$ of $\mathrm{Cu}-\mathrm{HTF}$. 


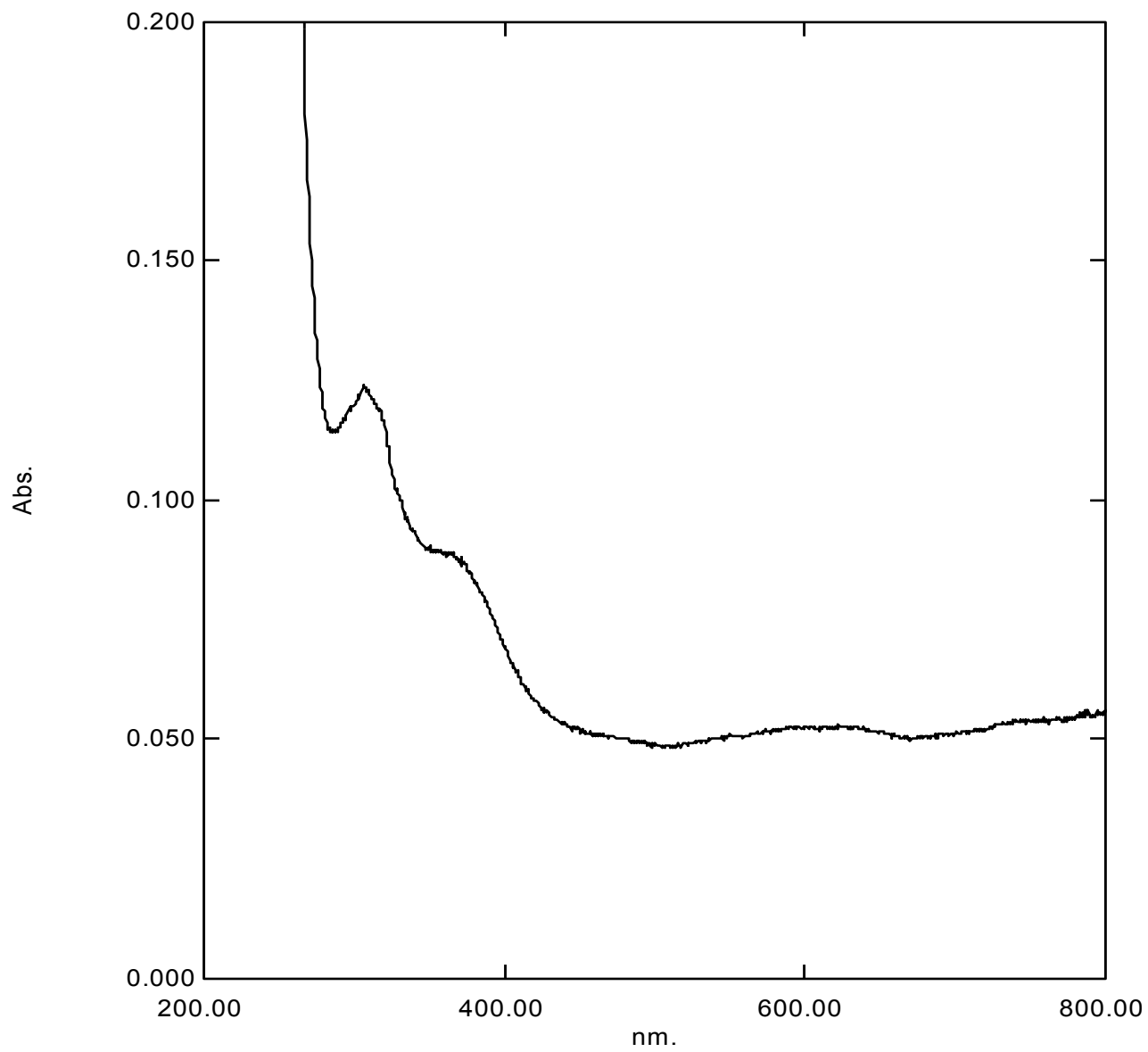

Fig. (4a). UV-absorption spectrum of solution containing $\mathrm{Cu}-\mathrm{HTF}$.

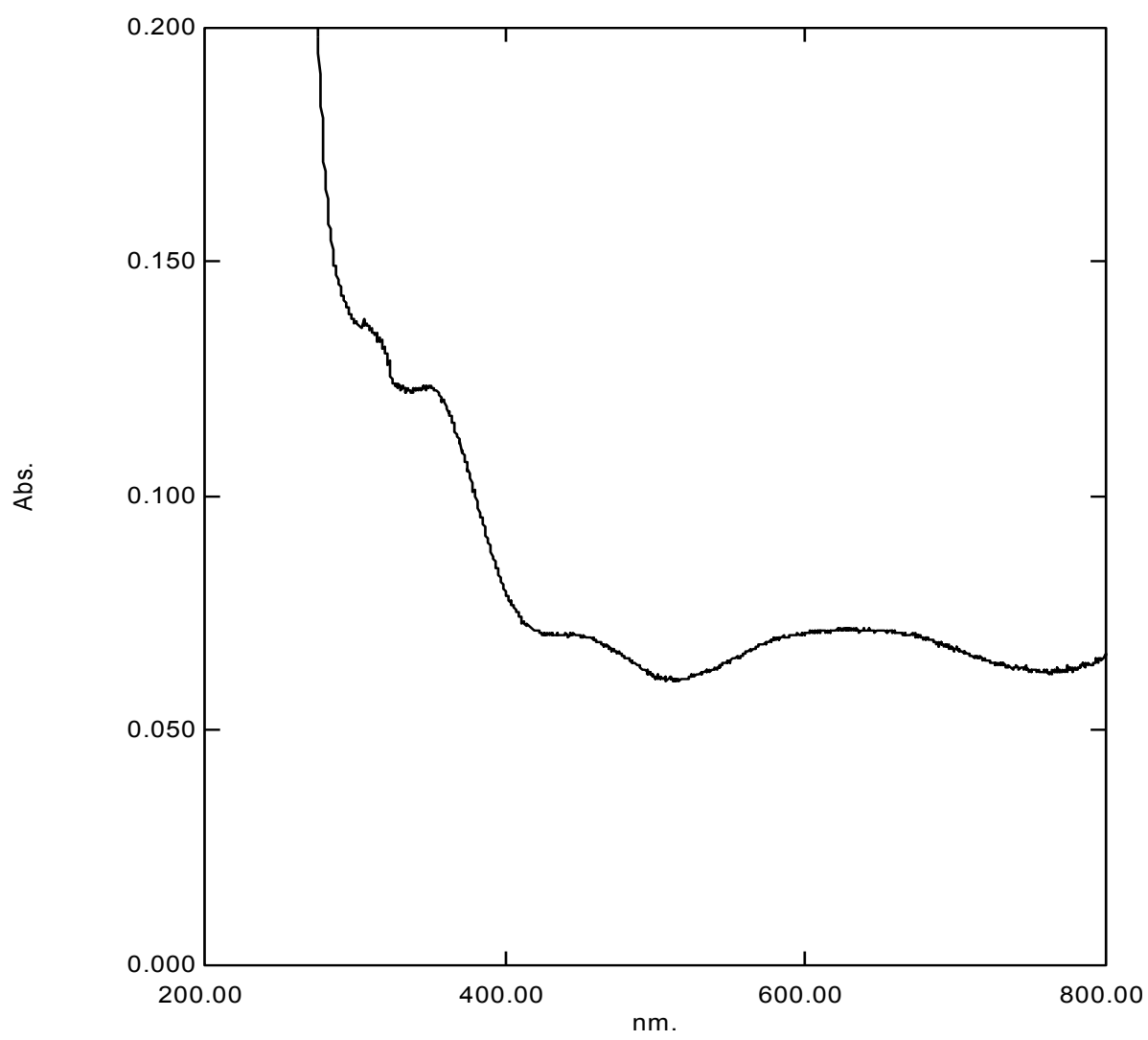

Fig. (4b). UV-absorption spectrum of solution containing HTF-Fe ${ }^{2+}$. 


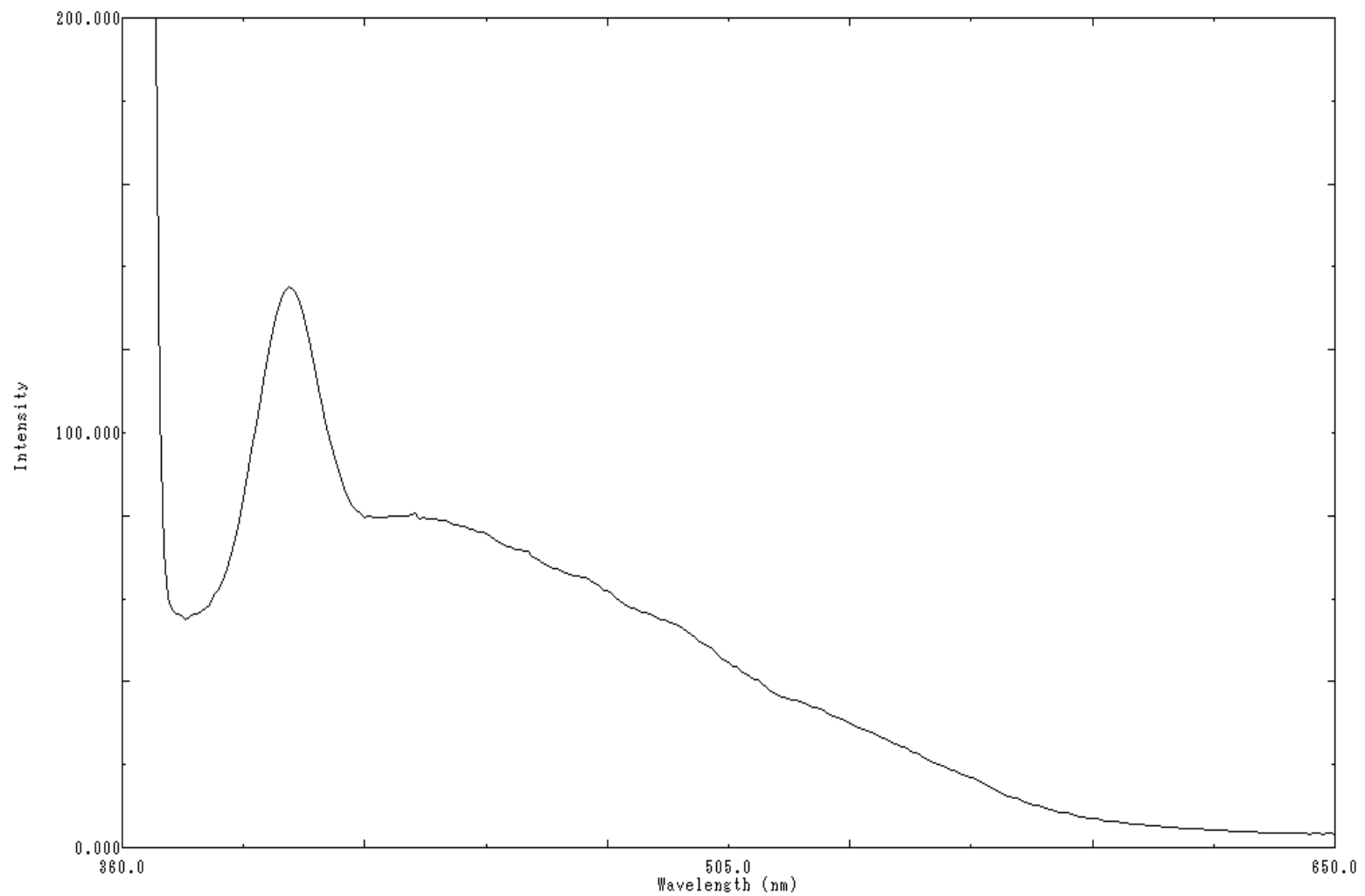

Fig. (5a). Fluorescence spectrum of $\mathrm{Cu}-\mathrm{HTF}$ solution.

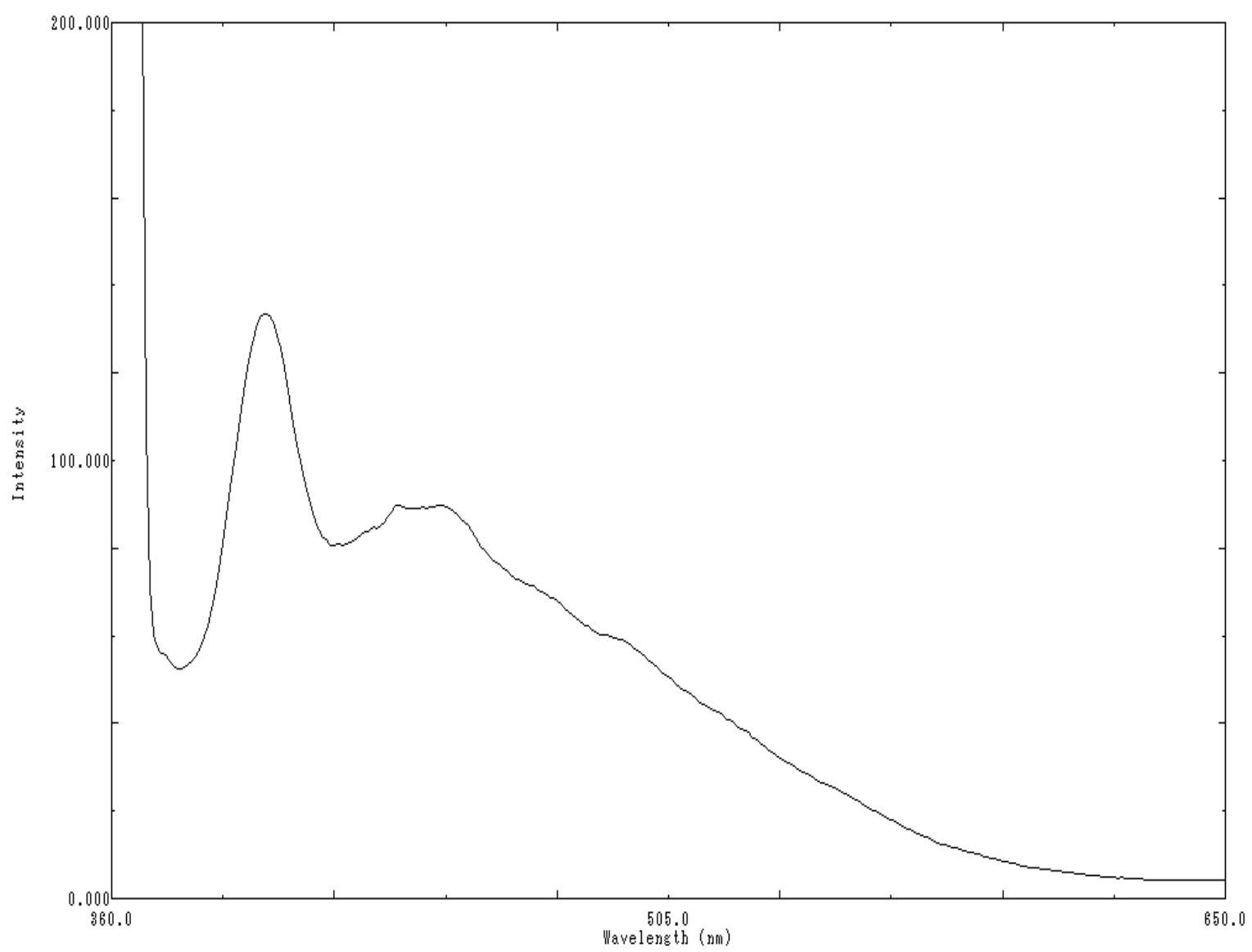

Fig. (5b). Protective film is formed on the surface of mild steel after immersion in the solution containing $50 \mathrm{ppm}$ of $\mathrm{Cu}-\mathrm{HTF}$. 
It is proposed that oxygen atom of phenolic group and nitrogen atom of pyridine ring have coordinated with $\mathrm{Fe}^{2+}$ and $\mathrm{HTF}-\mathrm{Fe}^{2+}$ is formed on the mild steel surface. The structure of the resulting HTF-Fe ${ }^{2+}$ complex is shown in Fig. (6).

This view is in agreement with the structure proposed by Albrecht et al. for zinc complex [14].

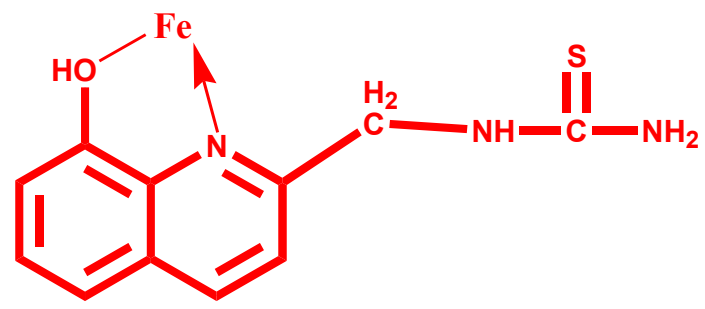

Fig. (6). Structure of $\mathrm{Fe}^{2+}$ complex.

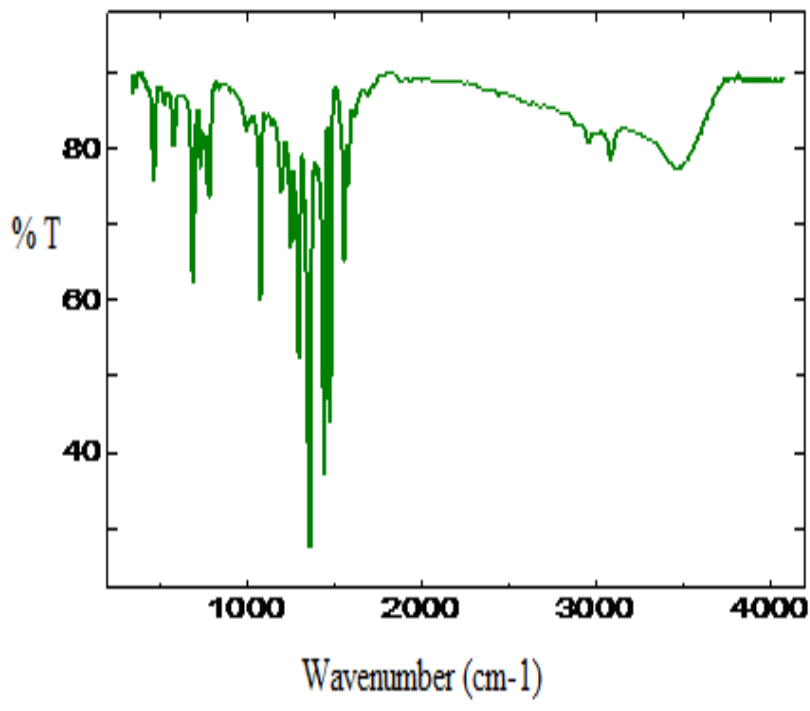

Fig. (7a). FTIR spectrum of pure $\mathrm{Cu}-\mathrm{HTF}$.

The FTIR spectrum $(\mathrm{KBr})$ of the film formed on the mild steel surface after immersion in an aqueous solution containing $60 \mathrm{ppm}$ of $\mathrm{Cl}^{-}+50 \mathrm{ppm}$ of $\mathrm{Cu}-\mathrm{HTF}$ for a period of $24 \mathrm{hrs}$ is shown in Fig. (7b). The pyridine nitrogen

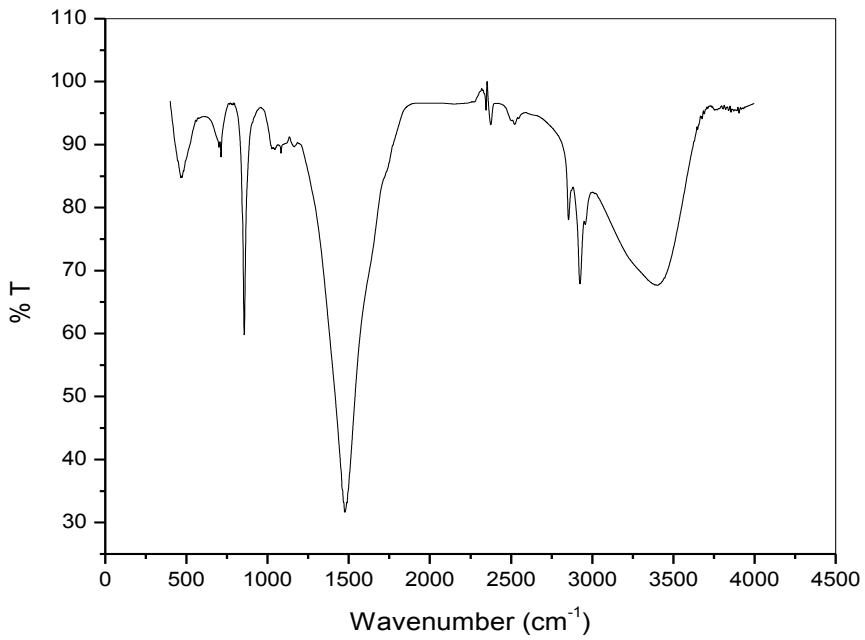

Fig. (7b). FTIR spectrum of film formed on mild steel surface after immersion in solution containing $60 \mathrm{ppm} \mathrm{Cl}^{-}+50 \mathrm{ppm}$ of $\mathrm{Cu}-\mathrm{HTF}$. (a)

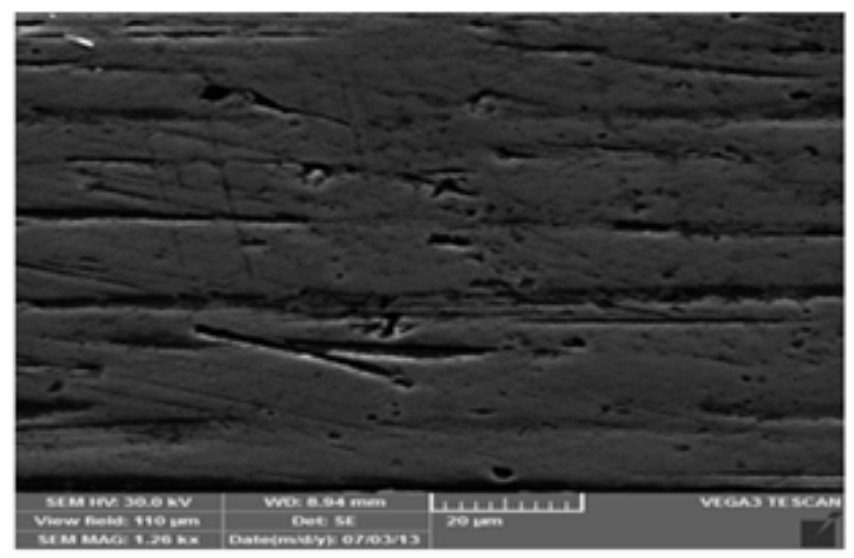

(b)

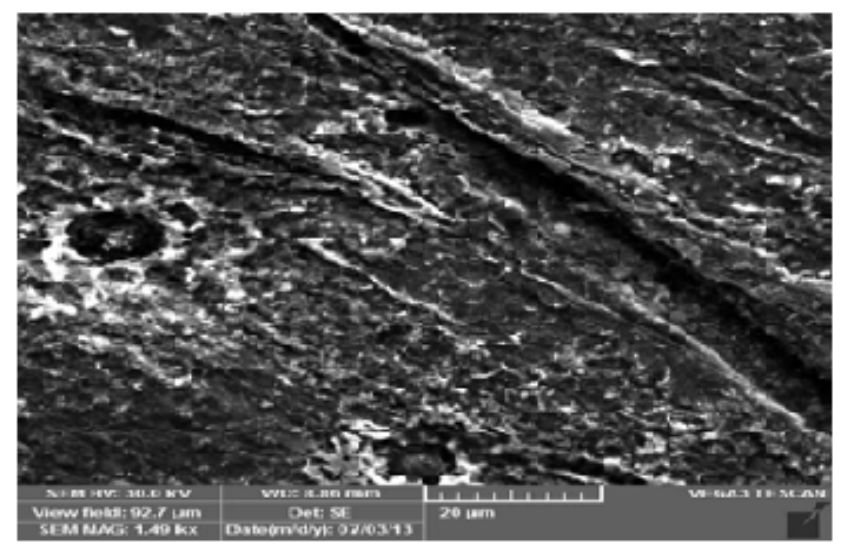

(c)

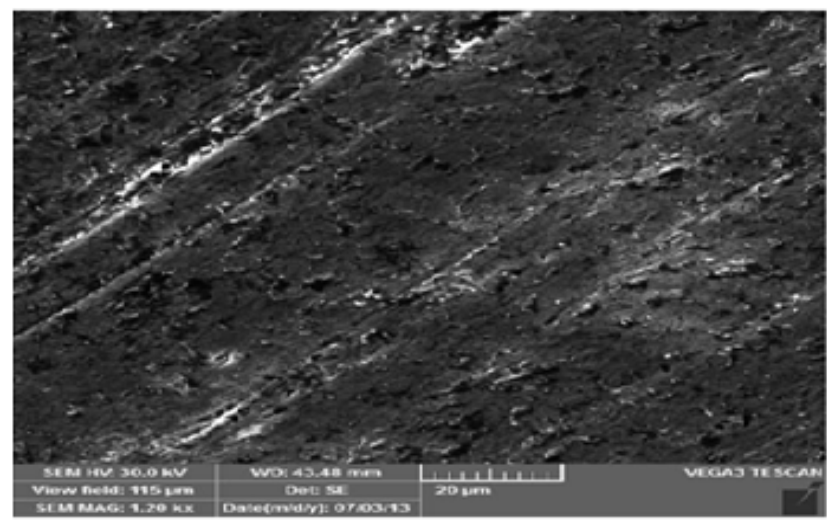

Fig. (8). (a) SEM analysis of mild steel; magnification $\times 20$ (control). (b) Mild steel is immersed in an aqueous solution containing $60 \mathrm{ppm}$ of $\mathrm{Cl}^{-}$, magnification $\times 20$ (blank). (c) Mild steel is immersed in an aqueous solution containing $60 \mathrm{ppm}$ of $\mathrm{Cl}^{-}+50$ ppm of $\mathrm{Cu}$ - HTF magnification $\times 20$.

frequency has shifted from $1596.77 \mathrm{~cm}^{-1}$ to $1500.00 \mathrm{~cm}^{-1}$. The CH stretching frequency has shifted from $3045.05 \mathrm{~cm}^{-1}$ to $2920.02 \mathrm{~cm}^{-1}$. The $\mathrm{C}=\mathrm{S}$ stretching frequency appears at $1110.08 \mathrm{~cm}^{-1}$. The additional peak obtained in the region of $490.10 \mathrm{~cm}^{-1}$ due to HTF-Fe ${ }^{2+}$ complex. Thus it is concluded that oxygen atom of phenolic group and nitrogen atom of pyridine ring have coordinated with $\mathrm{Fe}^{2+}$ and $\mathrm{HTF}-\mathrm{Fe}^{2+}$ complex is formed on the mild steel surface. 
(a)

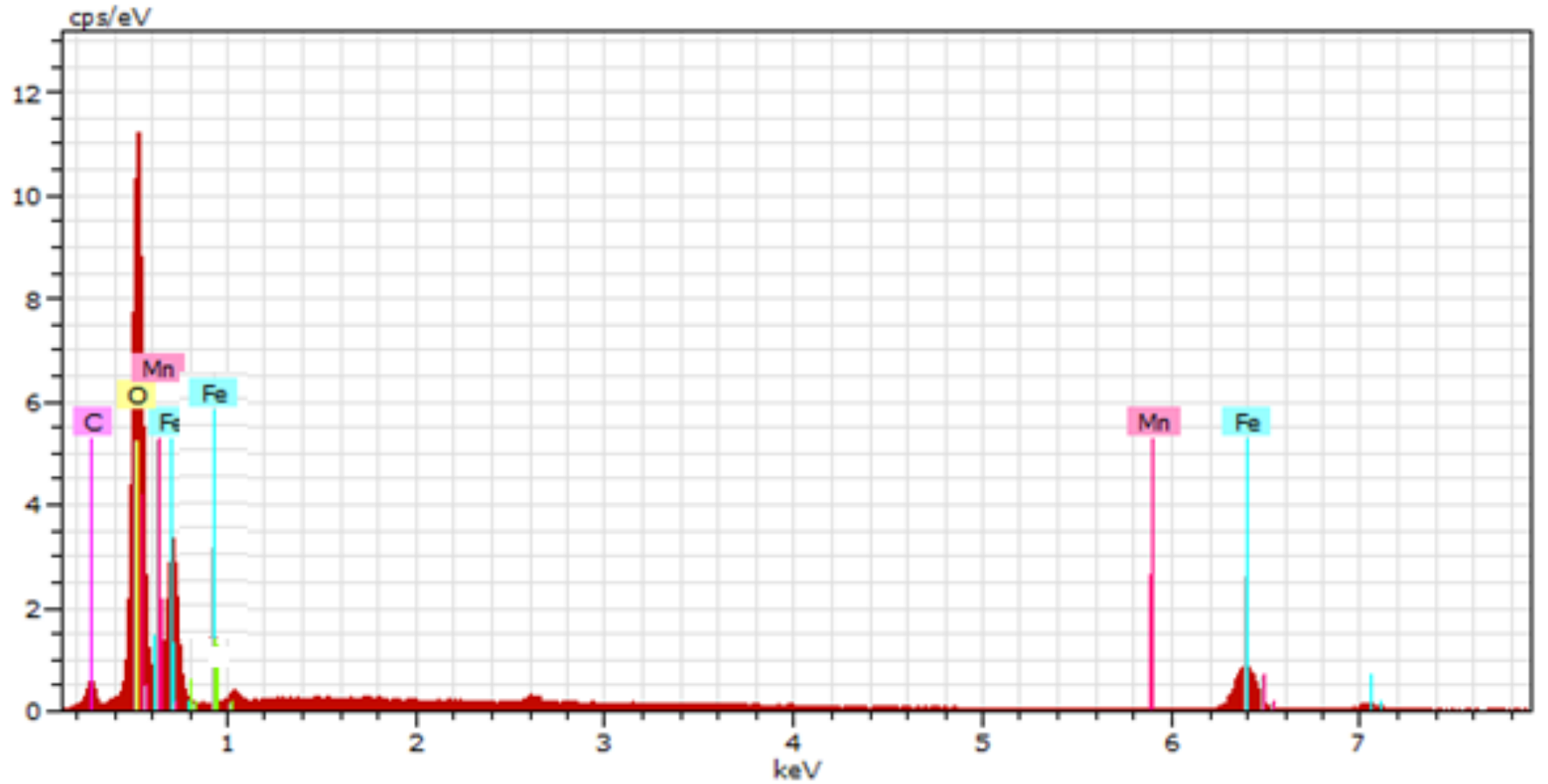

(b)

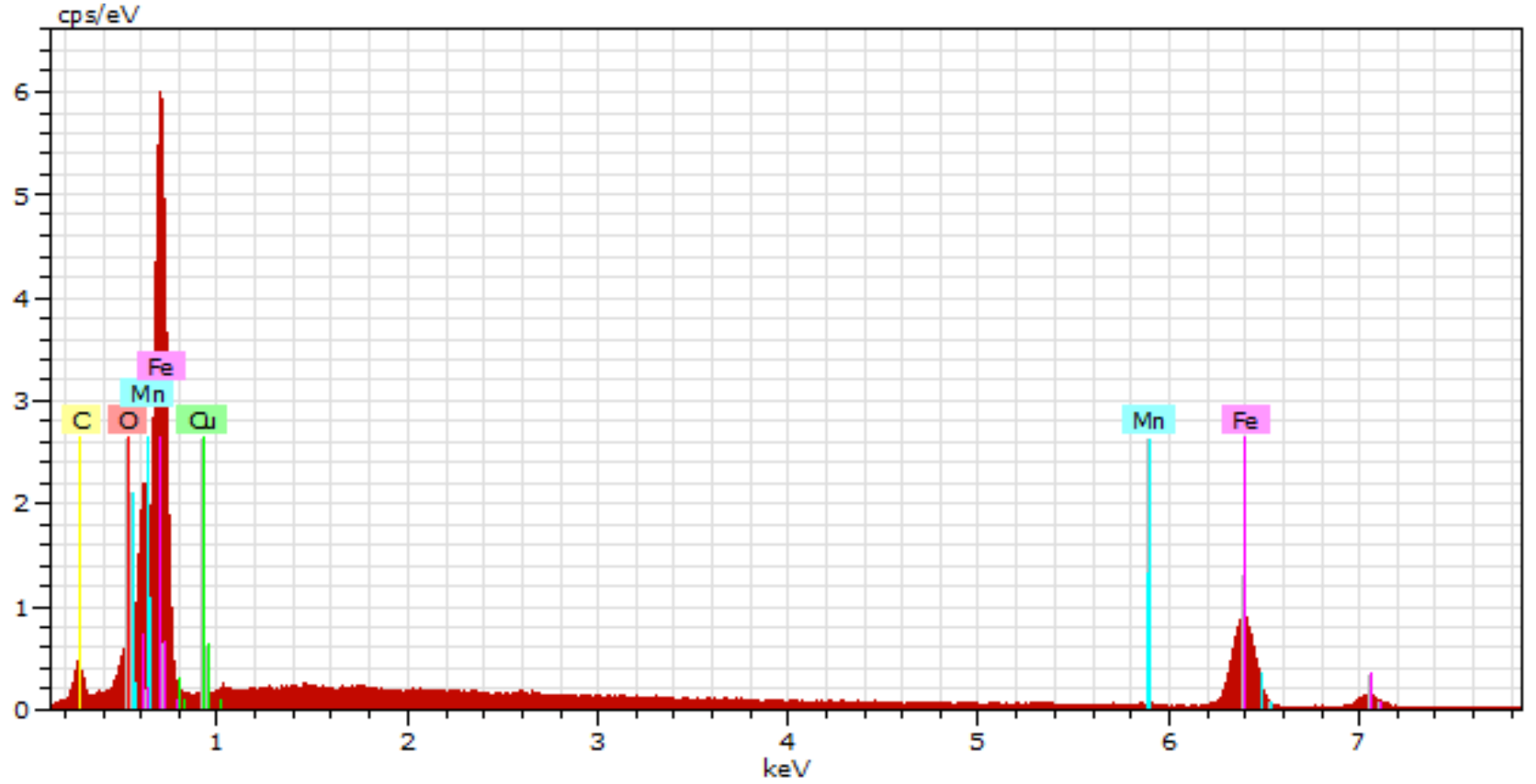

Fig. (9). EDAX spectra of (a) Mild steel sample after immersion in the aqueous solution containing $60 \mathrm{ppm}^{\circ} \mathrm{Cl}^{-}$. (b) $\mathrm{Mild}^{-3}$ steel sample after immersion in the aqueous solution containing $60 \mathrm{ppm}^{-} \mathrm{Cl}^{-}+50 \mathrm{ppm}$ of $\mathrm{Cu}-\mathrm{HTF}$.

Table 4. Colonies forming unit (CFU) of mild steel in an aqueous solution containing $60 \mathrm{ppm}^{-} \mathrm{Cr}^{-}$in the absence and presence of $\mathrm{Cu}-\mathrm{HTF}$ inhibitor obtained by bacterial enumeration count method.

\begin{tabular}{|c|c|c|c|c|}
\hline \multirow{2}{*}{ Systems } & \multicolumn{4}{|c|}{ Colonies Forming Unit (per ml) } \\
\cline { 2 - 5 } & E. coli & Streptococcus & Pseudomonas & Enterobacter \\
\hline \hline $60 \mathrm{ppmCl}^{-}$ & $140 \times 10^{6}$ & $146 \times 10^{6}$ & $130 \times 10^{6}$ & $127 \times 10^{6}$ \\
\hline $60 \mathrm{ppm} \mathrm{Cl}^{-}+50 \mathrm{ppm} \mathrm{Cu}-\mathrm{HTF}$ & $56 \times 10^{6}$ & $52 \times 10^{6}$ & $50 \times 10^{6}$ & $53 \times 10^{6}$ \\
\hline
\end{tabular}




\section{Analysis of FTIR Spectra}

The FTIR spectra have been used to analyze the film formed on the mild steel surface [25-27]. The FTIR spectrum $(\mathrm{KBr})$ of pure $\mathrm{Cu}-\mathrm{HTF}$ is shown in Fig. (7a). The $\mathrm{C}=\mathrm{S}$ stretching frequency appears at $1110.8 \mathrm{~cm}^{-1}$. The $\mathrm{CH}$ stretching frequency appears at $3045.05 \mathrm{~cm}^{-1}$. The peak due to secondary nitrogen $(\mathrm{NH})$ appears at $3127.97 \mathrm{~cm}^{-1}$. The peak due to pyridine nitrogen $(\mathrm{C}=\mathrm{N})$ appears at $1596.77 \mathrm{~cm}^{-1}$. The peak due to aromatic $\mathrm{C}=\mathrm{C}$ appears at $1498.42 \mathrm{~cm}^{-1}$.

\section{SEM Analysis of Mild Steel Surface}

SEM provides a pictorial representation of the surface of mild steel. To understand the nature of the surface film in the absence and presence of inhibitors and the extent of corrosion of mild steel, the SEM micrographs of the surface are examined [28-30]. The SEM images of different magnification $(\times 20)$ of mild steel specimen immersed in an aqueous containing $60 \mathrm{ppm}$ $\mathrm{Cl}^{-}$for one day in the absence and presence of inhibitor system are shown in Fig. (8a-c) respectively. The SEM micrographs of polished mild steel surface (control) in Fig. (8a) show the smooth surface of the mild steel. This shows the absence of any corrosion products (or) inhibitor complex formed on the mild steel surface. The SEM micrographs of mild steel immersed in the aqueous containing $60 \mathrm{ppm} \mathrm{Cl}^{-}$(Fig. 8b) show the roughness of the mild steel surface which indicates the highly corroded area of mild steel. However, Fig. (8c) indicates that in the presence of inhibitor ( $\left.60 \mathrm{ppm} \mathrm{Cl}^{-}+50 \mathrm{ppm} \mathrm{Cu}-\mathrm{HTF}\right)$ the rate of corrosion is suppressed, as can be seen from the decrease of corroded areas. The mild steel surface is almost free from corrosion due to the formation of insoluble complex on the surface of the mild steel [30].

\section{Energy Dispersive Analysis of X-Rays (EDAXs)}

The EDAXs survey spectra were used to determine the elements present on the mild steel surface before and after exposure to the inhibitor solution [28-30]. The objective of this section was to confirm the results obtained from chemical and electrochemical measurements that a protective surface film of inhibitor is formed on the mild steel surface. To achieve this, EDAX examinations of the mild steel surface were performed in the absence and presence of inhibitor system [29-31].

EDAX spectrum of mild steel immersed in the aqueous solution containing $60 \mathrm{ppm} \mathrm{Cl}^{-}$is shown in Fig. (9a). They show the characteristics peaks of some of the elements constituting the mild steel sample. The EDAX spectrum of mild steel immersed in the aqueous solution containing $60 \mathrm{ppm} \mathrm{Cl}^{-}+50 \mathrm{ppm} \mathrm{Cu}-\mathrm{HTF}$ is shown in Fig. (9b). It shows the additional line characteristic for the existence of $\mathrm{Cu}$. In addition, the intensity of $\mathrm{O}$ signals is reduced and the intensity of Fe signal is increased. The appearance of $\mathrm{Cu}$ and $\mathrm{Fe}$ signal and this enhancement of $\mathrm{O}$ signal are due to the presence of inhibitor. These data show that mild steel surface covered the $\mathrm{Fe}, \mathrm{O}, \mathrm{Cu}$ and $\mathrm{Mn}$ atoms.

\section{Bacterial Enumeration Count}

The results of bacterial enumeration count $[32,33]$ of the aqueous solution containing $60 \mathrm{ppm}$ of $\mathrm{Cl}^{-}$and $60 \mathrm{ppm}$ of $\mathrm{Cl}-$ with $\mathrm{Cu}-\mathrm{HTF}$ inhibitor are presented in Table 4. The aqueous solution containing $60 \mathrm{ppm}$ of $\mathrm{Cl}^{-}$without inhibitor shows more bacterial count against the growth of pathogenic bacteria strains such as E. coli, Streptococcus, Pseudomonas and Enterobacter.
The aqueous solution containing $60 \mathrm{ppm}$ of $\mathrm{Cl}^{-}$with inhibitor $\mathrm{Cu}-\mathrm{HTF}$ shows less bacterial count against the growth of pathogenic bacteria strains such as E. coli, Streptococcus, Pseudomonas and Enterobacter. A good result was obtained when addition of $\mathrm{Cu}-\mathrm{HTF}$ inhibitor to the corrosive media.

\section{CONCLUSION}

The present study leads to the following conclusions. The formulation consisting of $60 \mathrm{ppm}$ of $\mathrm{Cl}^{-}$and $50 \mathrm{ppm}$ of $\mathrm{Cu}-$ HTF offers 79\% inhibition efficiency in controlling corrosion of mild steel. Polarization study suggests that cathodic reaction is controlled predominantly. AC impedance spectra indicate that a protective film is formed on the mild steel surface. Fluorescence and UV-Visible spectra reveals that the protective film consists of $\mathrm{HTF}-\mathrm{Fe}^{2+}$ complex is formed on mild steel surface. SEM and EDAX confirm the presence of a protective film on the mild steel surface. The bacterial enumeration has been reduced by the addition of $\mathrm{Cu}-\mathrm{HTF}$ inhibitor to the corrosive media.

\section{CONFLICT OF INTEREST}

The authors confirm that this article content has no conflict of interest.

\section{ACKNOWLEDGEMENTS}

The authors are thankful to their management of Jamal Mohamed College, Tiruchirappalli, Tamilnadu, India. S.S. Syed Abuthahir and Dr. S. Rajendran are thankful to Dr. R. Saravanan, Director, B. Kothandaraman, CEO and Dr. K.V. Kuppusamy, Chairman of RVS Educational Trust's Group of Institutions, Dindigul-05, Tamilnadu, India.

\section{REFERENCES}

[1] (a) Brasher D. Nature 1962; 193: 868. (b) Brasher D, Mercer A Brit Corros J 1968; 3(3): 136. (c) Mercer A, Jenkins I. Brit Corros J 1968; 3(3): 144.

[2] Hackerman N. The theory and practice of corrosion and its control in industry. Langmuir 1987; 3(6): 922.

[3] Nestle A, Nathan CC. Corrosion inhibitors in petroleum production primary recovery. Ed.NACE, Houston, Texas, (USA), 1973.

[4] Cepak L, Adam J, Grygar T, et al. Oxidative dehydrogenation of ethane over vanadium supported on mesoporous materials of M41S family. Appl Catal A 2008; 342: 99.

[5] Pereira C, Rosa SA, Carvalho AP, et al. Vanadylacetylacetonate anchored onto amine-functionalised clays and catalytic activity in the epoxidation of geraniol. J Mol Catal 2008; 283(1-2): 5-14.

[6] Pereira C, Patricio S, Rosa SA, et al. Copper acetylacetonate anchored onto amine- funtionalised clays. J Colloid interf Sci 2007; 316: 570 .

[7] Fujihara S. Sol-gel processing of fluoride and oxyfluoride materials, in: H. Kozuka (Ed.), Handbook of Sol-Gel Science and Technology: Volume 1- Sol-Gel Processing, Kluwer Academic Publishers 2005; 219.

[8] Cernea M, Monnereau O, Llewellyn P, et al. Sol-Gel synthesis and characterization of Ce doped- $\mathrm{BaTiO}_{3}$. J Eur Ceram Soc 2006; 26: 3241 .

[9] Tangwiwat S, Milne SJ. Barium titanate sols prepared by a diol based sol-gel route. J Non-Cryst Solids 2005; 351: 976.

[10] Harms H, Volkland HP, Repphun G, et al. Action of chelators on solid iron in phosphate- containing aqueous solutions. Corros Sci 2003; 45: 1717.

[11] Hettiarachchi S. Palladium acetylacetonate solution. European Patent. EP0651073, 1995.

[12] Gerloch M. Constable, Transition Metal Chemistry. VCH Verlagsgessellschaft mbH, Weinhein 1994, p. 176.

[13] Isabel G, Jesus S, Ana MG, Matilde F, Esther G. Srtuctural and spectroscopic studies on some metal complexes of an 8-hydroxy quinoline derivative. Inorganica Chimica Acta 2010; 363: 193-8. 
[14] Markus A, Karen W, Patrick W, Elina W, Roland F. Zinc(II) complexes of amide and urea-substituted 8-hydroxyquinolines. Inorganica Chimica Acta 2002; 341: 25-32.

[15] Sahaya RA, Rajendran S, Nagalakhsmi R, et al. Eco-friendly Inhibitor glycine- $\mathrm{Zn}^{2+}$ system controlling corrosion of carbon steel in well water. Eur Chem Bull 2012; 1: 130.

[16] Nagalakshmi R, Rajendran S, Sathiyabama J, et al. Corrosion behaviour of metals in artificial urine in presence of sodium chloride. Eur Chem Bull 2013; 2: 150.

[17] Sribharathy V, Rajendran S, Rengan P, et al. Corrosion inhibition by an aqueous extract of aloavera (L), burm (F). Liliacea Eur Chem Bull 2013; 2(7): 471-76.

[18] Agiladevi S, Rajendran S, Jeyasundari J, et al. Corrosion resistance of metals in simulated ringer solution-A. Eur Chem Bull 2013; 2: 503 .

[19] Johnsirani V, Rajendran S. Sathiyabama J, et al. Inhibitive action of malachite green- Zn2+ system. Bulgarian Chem Commun 2012; 44(1): 41-51.

[20] Agnesia KS, Rajendran S. Realization of synergism in sodium tungstate- $\mathrm{Zn}^{2+}-\mathrm{N}$-(Phosphenomethyl) iminodiaceticacid system in well water. Open Corrs J 2009; 2: 166-74.

[21] Shyamala DB, Rajendran S. Corrosion inhibition by trisodiumcitrate (TSC $-\mathrm{Zn}^{2+}$ System). Eur Chem Bull 2012; 1: 150.

[22] Rajendran S, Paulraj J, Rengan P, et al. Corrosion behavior of metals in artificial saliva in presence of spirulina powder. J Dent Oral Hyg 2009; $1: 1$

[23] Rajendran S, Apparao BV, Palniswamy N. Technical note calcium gluconate as corrosion inhibitor for mild steel in low chloride media. British Corros J 1998; 33 (4): 315-7.

[24] Jayasundari J, Rajendran S, Sayee R, et al. Electrochemical and surface analysis studies on corrosion inhibition of carbon steel. Eur Chem Bull 2013; 2: 585.
[25] Mary AC, Rajendran S, Vijaya N, et al. Corrosion inhibition by an ion pair reagent- $\mathrm{Zn}^{2+}$ system. Open Corros J 2012; 5: 1-7.

[26] Rajendran S, Jeyasundari J, Usha P, et al. Corrosion behaviour of aluminium in the presence of an aqueous extract of hibiscus rosasinensis. Portugaliae Electochim Acta 2009; 27(2): 15-64.

[27] Gopi D, Manomozhi S, Govindaraju KM, et al. Surface and electrochemical characterization of pitting corrosion behavior of 304 stainless steel in ground water media. J App Electrochem 2007; 37: 439 .

[28] Amin MA, Abd El-Rehim SS, El-Sherbini EFF, et al. The inhibition of low carbon steel corrosion in hydrochloric acid solutions by succinic acid. Part I. Weight loss, polarization, EIS, PZC, EDX and SEM studies. Electrochimica Acta 2007; 52: 3588.

[29] Amin MA, Abd El-Rehim SS, Abdel- Fatah. Electrochemical frequency modulation and inductively coupled plasma atomic emission spectroscopy methods for monitoring corrosion rates and inhibition of low alloy steel corrosion in $\mathrm{HCl}$ solutions and a test for validity of the Tafel extrplotation method. Corros Sci 2009; 51 882 .

[30] Rahim SSA, Hazzazi OA, Amin MA, Khelad KF. On the corrosion inhibition of low carbon steel in concentrated sulphuric acid solutions. Part I: chemical and electrochemical (AC and DC) studies. Corros Sci 2008; 50: 2258.

[31] Migahed MA, Azzam EMS, Morsy SMJ. Electrochemical behavior of carbon steel in acid chloride solution in the presence of dodecyl cysteine hydrochloride self-assembled on gold nanoparticles. Corros Sci 2009; 51: 1636-44.

[32] Jackie Reynolds/Mark Farinha. Richland College 2005

[33] Rajendran S, Apparo BV, Palaniswamy N. Synergistic and biocidal effects of HEDP-Zn2+ - CTAB system on the inhibition of corrosion of mild steel in neutral aqueous environment. Bull Electrochem 2000; 166: 209 .

(C) Abuthahir et al.; Licensee Bentham Open.

This is an open access article licensed under the terms of the Creative Commons Attribution Non-Commercial License (http://creativecommons.org/licenses/ by-nc/3.0/) which permits unrestricted, non-commercial use, distribution and reproduction in any medium, provided the work is properly cited. 